\title{
BARIUM-RICH, OLIVINE-MICA LAMPROPHYRES WITH AFFINITIES TO LAMPROITES, FROM THE MT BUNDEY AREA, NORTHERN TERRITORY, AUSTRALIA.
}

\author{
Sheppard, S.; Taylor, W.R. and Rock, N.M.S.
}

Key Centre for Strategic Mineral Deposits, University of Western Australia, Nedlands, W.A. 6009, Australia.

Potassic igneous rocks, transitional between lamproites of continental intra-plate settings and shoshonitic volcanic and lamprophyric rocks (e.g. minettes) of active continental margins, are known from several localities world-wide but their petrogenesis, tectonic setting and relationship to Ti-rich lamproites are poorly understood. Lack of detailed mineralogical and geochemical documentation of such 'transitional lamproites' has contributed to difficulties in distinguishing them from true lamproites. In this abstract we describe an occurrence of unusual olivine-mica lamprophyre dykes which intrude Early Proterozoic, low-grade metasediments and granitoids of the Mt Bundey area, Pine Creek Inlier, northern Australia. Their mineral assemblages and mineral chemistry are typical of shoshonitic (calc-alkaline) lamprophyres, but their whole-rock chemistry more closely resembles lamproites.

The Mt Bundey lamprophyres are spatially and probably genetically associated with a post-tectonic, composite syenite-granite pluton. Numerous dykes of $0.5-3.0 \mathrm{~m}$ thickness intrude the granite and syenite; contacts with the pluton are sharp and margins of the dykes may be chilled. Rb-Sr isotopic data shows that the lamprophyres, syenite and granite fall on the same isochron defining an age of $1810 \pm 32 \mathrm{Ma}$ with an initial ${ }^{87} \mathrm{Sr} /{ }^{86} \mathrm{Sr}$ ratio of 0.7038 . A U/Pb age on zircons from the granite define a more precise age for the pluton, and thus for the lamprophyres, of $1832 \pm 6 \mathrm{Ma}$ (R.W. Page, written communication, 1990). The lamprophyres are composed of $1-5 \mathrm{~mm}$ phenocrysts of altered, euhedral olivine (5-30\%) and minor clinopyroxene, and up to $10 \%$ mica phenocrysts set in a groundmass of $\leq 0.5 \mathrm{~mm}$ orthoclase, mica, amphibole, clinopyroxene, minor magnetite, apatite and sphene, with accessory zircon and (?) monazite. Felsic globular structures composed of plagioclase, calcite and mica are a minor ( $<3 \%$ ) but widespread component of the dykes.

Olivine phenocrysts are completely replaced by chlorite, quartz and magnetite, and are surrounded by green-brown mica. Phenocryst and groundmass mica compositions mainly fall in the biotite field (mg\#= 54-72). The most common type of biotite is dark green with abundant acicular inclusions of (?) Ti-oxide usually zoned to pale rims free of inclusions. The other type of biotite is pale orange-brown, with dark 'rims reflecting a slight decrease in $\mathrm{Mg} / \mathrm{Fe}$ ratios. The two types have similar compositions and appear to be distinguishable from each other only on the basis of the higher $\mathrm{Fe}^{3+} / \mathrm{Fe}^{2+}$ ratio of the green biotite. Biotite compositions (2-8wt\% $\mathrm{TiO}_{2}$ and $\left.12.0-13.5 \mathrm{wt} \% \mathrm{Al}_{2} \mathrm{O}_{3}\right)$ fall within the calc-alkaline lamprophyre field on $\mathrm{Al}_{2} \mathrm{O}_{3}-\mathrm{TiO}_{2}$ and $\mathrm{Al}_{2} \mathrm{O}_{3} / \mathrm{TiO}_{2}-\mathrm{MgO} / \mathrm{FeO}$ (T) diagrams but are generally displaced toward the lamproite field.

Feldspar is orthoclase $\left(\mathrm{Or}_{70-90}\right)$ and its low iron content ( $\leq 0.5 \mathrm{wt} \%$ $\mathrm{Fe}_{2} \mathrm{O}_{3}$ ) clearly distinguishes it from lamproitic feldspars $\left(1-5 \mathrm{wt} \% \mathrm{Fe}_{2} \mathrm{O}_{3}\right)$. Clinopyroxenes are diopsides ( $\mathrm{Mg}_{80-86}, 0.7 \mathrm{wt} \% \mathrm{TiO}_{2}, 1.2-3.3 \mathrm{wt} \% \mathrm{Al}_{2} \mathrm{O}_{3}$ ) which fall within the calc-alkaline lamprophyre field, but toward lamproitic compositions on $\mathrm{SiO}_{2} / \mathrm{TiO}_{2}-\mathrm{MgO} / \mathrm{FeO}(\mathrm{T})$ and $\mathrm{TiO}_{2}-\mathrm{Al}_{2} \mathrm{O}_{3}$ diagrams. Crystals commonly display oscillatory zoning superimposed on gradational zoning toward more $\mathrm{TiO}_{2}$-rich, MgO-poor rims. Amphiboles are tremolites (52-57wt\% $\mathrm{SiO}_{2}$, <0.8wt\% $\mathrm{TiO}_{2}$ and $\sum$ alkalis <2 wt\%, commonly $\leq 1$ wt\%) with 
minor edenite substitution. They plot within the field of "mainly secondary amphiboles" on a $\mathrm{TiO}_{2}-\mathrm{SiO}_{2}$ diagram (Fig. 4.4; Rock, 1990), an origin supported by rare cores of diopside to the tremolite. The only oxide phase present in most dykes is a $\mathrm{TiO}_{2}-$ and $\mathrm{Cr}_{2} \mathrm{O}_{3}-$ poor $\left(<0.2\right.$ wt\% $\mathrm{TiO}_{2}$ and $<0.1$ wt\% $\mathrm{Cr}_{2} \mathrm{O}_{3}$ ) magnetite, although chromian magnetite (13-15 wt: $\mathrm{Cr}_{2} \mathrm{O}_{3}$ ) is a rare mineral in some samples. The above mineral compositions together with the absence of richterite, leucite, groundmass tetraferriphlogopite and the minor titanate minerals that characterize lamproites, demonstrate that the Mt Bundey dykes have closest mineralogical affinity with shoshonitic mica lamprophyres (minettes).

No mantle or crustal xenoliths have been found in the dykes, but some contain xenocrysts of partly resorbed perthite and quartz derived from the granite-syenite pluton. Many of the dykes contain (?) cognate xenoliths, 0.5-1.0 mm in diameter, composed of amphibole and minor biotite and magnetite. These observations are consistent with $\mathrm{Pb}$ isotope data which indicate negligible upper crustal contamination of the lamprophyres.

The Mt Bundey lamprophyres have $46-49$ wt $\% \mathrm{SiO}_{2}, \sim 1.5-2$ wt\% $\mathrm{TiO}_{2}$, 8-12 wt $\% \mathrm{MgO}, \sim 2$ wt $\mathrm{Na}_{2} \mathrm{O}$ and $\sim 5-7.5$ wt $\% \mathrm{~K}_{2} \mathrm{O}$. Magnesium numbers (mg\#) lie in the range 65 to 75 (assuming atomic $\mathrm{Fe}^{3+} / \mathrm{Fe}^{2+}=0.3$ ). Those lamprophyres with the highest mg\#s contain $>350 \mathrm{ppm} \mathrm{Ni}$ and $>600 \mathrm{ppm} \mathrm{Cr}$ and are therefore candidates for primary melts of mantle peridotite. Minor olivine \pm clinopyroxene fractionation may be important in generating the less magnesian lamprophyres. Relative to typical minettes the Mt Bundey lamprophyres are more strongly enriched in $\mathrm{Ta}, \mathrm{Nb}, \mathrm{Th}, \mathrm{U}, \mathrm{Ba}, \mathrm{P}, \mathrm{Zr}$ and REE but have comparable Sr, F, Sc, V and $\mathrm{Cr}$ contents. The dykes contain similar levels of $\operatorname{Zr}(650-930 \mathrm{ppm}), \operatorname{Sr}(1600-3700 \mathrm{ppm})$, La (165-260 ppm), F (3500-4900 ppm) and $\mathrm{Ba}(4600-10000 \mathrm{ppm})$ to lamproites (see Rock, 1990) but they are not peralkaline (molar $\left[\mathrm{K}_{2} \mathrm{O}+\mathrm{Na}_{2} \mathrm{O}\right] / \mathrm{Al}_{2} \mathrm{O}_{3}=0.8-1.0$ ). The closest analogues to the Mt Bundey lamprophyres are jumillites from SE Spain and cocites from northern Vietnam.

On mantle-normalized abundance diagrams (Fig.1), the Mt Bundey dykes show negative $\mathrm{Ta}-\mathrm{Nb}$ and $\mathrm{Ti}$ anomalies - a feature characteristic of subduction-related magmas. The magnitude of the Ta-Nb anomaly is, however, intermediate between typical subduction-related minettes, which have much larger negative anomalies, and Ti-rich lamproites, which either lack such anomalies or have slight $\mathrm{Ta}-\mathrm{Nb}$ anomalies (see Fig.1 and also Foley and Wheller, 1990). The intermediate nature of the Mt Bundey dykes is further illustrated on a $\mathrm{Zr}-\mathrm{Nb}$ plot (Fig. 2). Both the Mt Bundey lamprophyres and the jumilites plot in a field intermediate between minettes associated with subduction or post-collisional settings and West Kimberley leucite-lamproites of continental intra-plate origin.

Current petrogenetic models for the transitional lamproites suggest they may be either (1) generated by partial melting above a 'fossil' subduction zone (e.g. Venturelli et al., 1984) or (2) generated in enriched sub-continental mantle in which the enrichment event has no relationship to subduction processes but carries a subduction-type signature due to the stability of residual titanate minerals (e.g. Foley and Wheller, 1990). For the Mt Bundey lamprophyres, modelling of the $\mathrm{Sr}$ isotope data is consistent with enrichment of the source area $\sim 150-350$ Ma before partial melting, suggesting that model (1) may be appropriate if evidence can be found for a $\sim 1.9-2.0 \mathrm{Ga}$ calc-alkaline magmatic event in the Pine Creek Inlier. However, the detailed magmatic history of this region is not well known.

The presence of subduction-related (model 1) or residualtitanate-related (model 2) Ta-Nb-Ti anomalies in transitional lamproite magmas implies an oxidized mantle source region at depth $\left(\mathrm{fO}_{2}>\mathrm{FMQ}\right)$ (Foley and Wheller, 1990). Irrespective of the depth of generation, diamond or 
graphite will not be stable under these conditions and unless oxidation of the subcontinental mantle is only of very local extent, a transitional lamproite province is unlikely to be highly prospective for diamond.

\section{REEERENCES}

Foley, S.F. and wheller, G.E. (1990) Parallels in the origin of the geochemical signatures of island arc volcanics and continental potassic igneous rocks: the role of residual titanates. Chemical Geology, 85, 1-18. Rock, N.M.S. (1990) Lamprophyres. Blackie \& Sons Ltd, Glasgow.

Venturelli, G., Capedri, S., Di Battistini, G., Crawford, A., Kogarko, L.N., and Celestini, S. (1984) The ultrapotassic rocks from southeastern Spain, Lithos, 17, 37-54.

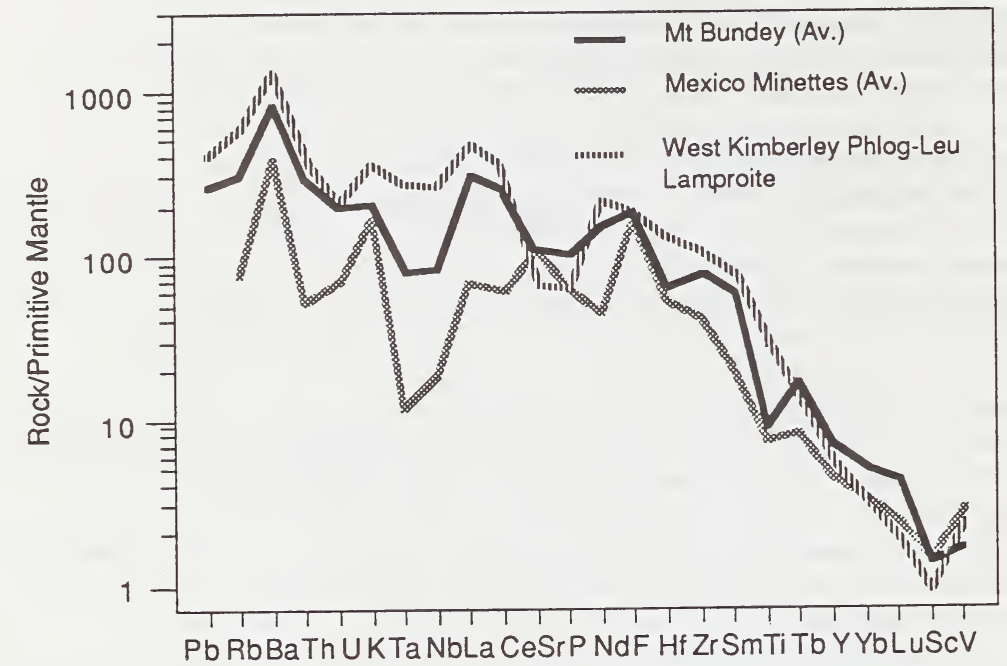

FIG. 1. Mantle normalised plot showing the intermediate nature of the Mt Bundey dykes relative to subduction-related minettes and a lamproite from the West Kimberley Province, Western Australia.

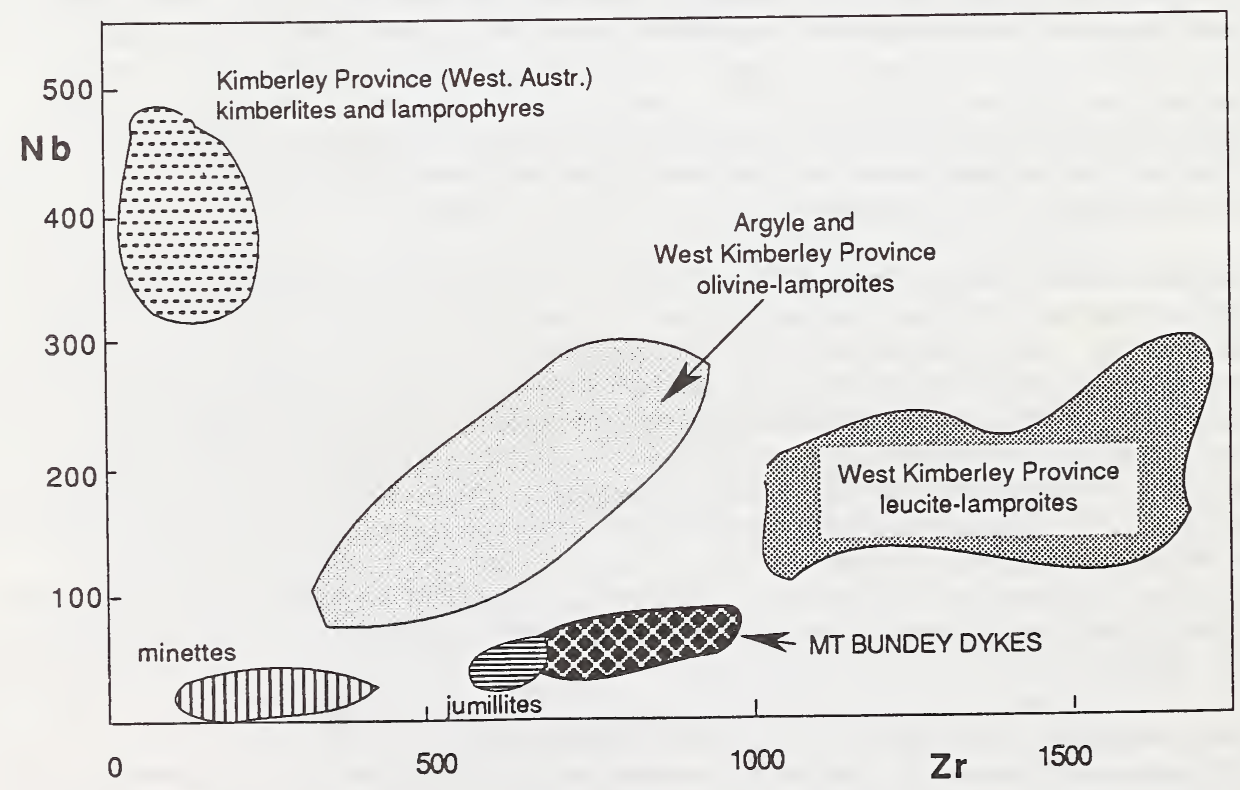

FIG. 2. $\mathrm{Nb}$ versus $\mathrm{Zr}$ plot (ppm) showing the intermediate nature of the Mt Bundey rocks and Spanish jumillites relative to minettes and West Kimberley Province (Western Australia) lamproites. 